\title{
Determining Irrigation Wetting Patterns Using Time Domain Reflectometry
}

\author{
Genevieve Pelletier and C.S. Tan ${ }^{1}$ \\ Agriculture Canada, Research Station, Harrow, Ontario NOR 1G0, Canada
}

Additional index words. Prunuspersica, available soil water

Abstract. A time domain reflectometry (TDR) technique was used to measure water in the soil profile to derive wetting patterns of drip and microjet irrigation systems in a peach [Prunus persica (L.) Batsch] orchard. A distinct cone shape of $>50 \%$ available soil water (ASW) extending from the emitter down to a depth of $>45 \mathrm{~cm}$ was observed in the drip system. The $50 \%$ ASW zone in the microjet system was an elongated semicircle from the soil's surface down to a depth of $35 \mathrm{~cm}$. TDR can be used successfully to determine wetting patterns of various irrigation systems to develop better irrigation scheduling.

Irrigation scheduling is a difficult management task that can be improved using time domain reflectometry (TDR). The goal of irrigation scheduling is to provide an adequate amount of water to plants in a timely fashion to meet their consumptive use while minimizing the potential for leaching caused by applying excesswater. Irrigation schedules can be evaluated by monitoring irrigation efficiency, which, in turn, depends on water application uniformity and efficiency of water infiltration into soils. These two factors have been studied extensively in relation to drip and sprinkler irrigation.

Water infiltration strongly depends on soil characteristics such as texture, structure, and hydraulic properties. It also depends on irrigation design criteria, such as application rate, total volume applied, and irrigation frequency (Jury and Earl, 1977; Risse and Chesness, 1989). Many researchers have attempted to analyze and model the infiltration process to locate wetting fronts (Ben-Asher et al., 1978; Healy and Warrick, 1988; Raats, 1971; Wooding, 1968). These irrigation boundaries are important because they are a measure of irrigation efficiency. Experimental data for soil moisture have been collected with tensiometers and gravimetric sampling to test infiltration models, and sequential photographs have been used to evaluate ponding areas on the soil's surface (Bresler et al., 1971; Clothier and Heiler, 1983; Clothier et al., 1985; Jury and Earl, 1977; Lafolie et al., 1989; Levin et al., 1979). Risse and Chesness (1979) used bromide as a tracer to locate the wetting front. All these procedures are tedious and disturb the environment in which they are used. TDR is being used increasingly to determine soil water content rapidly in situ (Brisco et al., 1992; Nadler et al., 1991; Topp and Davis,

Received for publication 31 Aug. 1992. Accepted for publication 29 Dec. 1992. The cost of publishing this paper was defrayed in part by the payment of page charges. Under postal regulations, this paper therefore must be hereby marked advertisement solely to indicate this fact.

${ }^{1}$ To whom reprint requests should be addressed.
1985; Topp et al., 1984). TDR determines the dielectric constant of a soil by measuring the transit time of a high-frequency electromagnetic pulse launched along a pair of parallel wave guides embedded in the soil. The dielectric constant is a function only of volumetric soil water content, not other physical properties of the soil. The dielectric constant is calibrated and converted to percent volumetric soil water content. This technique is a rapid, nondestructive method of measuring soil water content in field experiments.

The objective of this study was to show that TDR can be used to evaluate wetting patterns of various irrigation methods. As a result, discrepancies due to the combined effect of nonuniform water application and infiltration in the field could be corrected.

Irrigation treatments consisted of drip, microjet, and no supplemental irrigation. All treatments were replicated three times in a peach orchard at Ridge Farm, Harrow Research Station, Ontario. The drip irrigation treatment included two pressure-compensated emitters (NETAFIM Irrigation, N.Y.) with a flow rate of 4.5 liters $\cdot \mathrm{h}^{-1}$ at $138 \mathrm{kPa}$. The emitters were inserted into 13-mm (internal diameter) polyethylene pipe, $60 \mathrm{~cm}$ from the tree base on the north and south of each tree. The microjet treatment included one microjet (SOLCOOR, Los Angeles) located $5 \mathrm{~cm}$ from the base of each tree, with a $360^{\circ}$ spray pattern and a flow rate of 28.9 liters $h^{-1}$ at $138 \mathrm{kPa}$. The irrigation amount and frequency for drip and microjet treatments were determined using corrected long-term evaporation derived from a class A pan at a nearby weather station, tree age and density, number of emitters or microjets per tree, flow rate of emitter or microjet, and soil moisture retention characteristics (Tan and Layne, 1991). Irrigation through the drip system was applied $3.5 \mathrm{~h}$ every day and irrigation through the microjet system was applied $2.3 \mathrm{~h}$ every 2 days. Irrigation began in midMay and continued to early September.

TDR (Model 6050X1 Trase System; Soilmoisture Equipment Corp., Santa Barbara, Calif.) was used to measure volumetric soil water content. The relationship of the dielectric constant value to the volumetric water percentage in the TDR system was established by the company using various types of soils carefully prepared to accurately known volumes of water in soil. This relationship then was used to convert field measurement of dielectric constant automatically to the volumetric soil water content. The calibration curve showed only a minor difference $( \pm 2 \%)$ in the evaluation of the volumetric water content for all soil types. Field measurements of volumetric soil water content were taken on the south and north sides of each tree at $0,15,45,75$, and $105 \mathrm{~cm}$ away from the emitter, microjet, or tree (depending on the treatment). At each location, volumetric soil water content was measured using stainless steel wave guides inserted vertically from the soil's surface to 5-, 15-, 30-, and 45-cm depths. All readings were taken after 2 months of irrigation treatments.

The experiment was conducted on Fox sand (Hapludalf) that contained $83 \%$ sand, $12 \%$ silt, and $5 \%$ clay from 0 to $20 \mathrm{~cm}$ deep and $86 \%$ sand, $8 \%$ silt, and $6 \%$ clay from $20 \mathrm{~cm}$ downward. Field capacities were $0.207 \mathrm{~m}^{3} \cdot \mathrm{m}$ ${ }^{3}$ from 0 to $20 \mathrm{~cm}$ and $0.172 \mathrm{~m}^{3} \cdot \mathrm{m}^{-3}$ from $20 \mathrm{~cm}$ downward. Permanent wilting points (PWPs) were $0.067 \mathrm{~m}^{3} \cdot \mathrm{m}^{-3}$ ) from 0 to $20 \mathrm{~cm}$ and 0.057 $\mathrm{m}^{3} \cdot \mathrm{m}^{-3}$ from $20 \mathrm{~cm}$ downward. Therefore, $50 \%$ available soil water (ASW) corresponded to $0.137 \mathrm{~m}^{3} \cdot \mathrm{m}^{-3}$ from 0 to $20 \mathrm{~cm}$ deep and 0.115 $\mathrm{m}^{3} \cdot \mathrm{m}^{-3}$ from $20 \mathrm{~cm}$ downward (Tan and Fulton, 1981).

A profile of the volumetric soil water content near the drip emitters and microjets, as

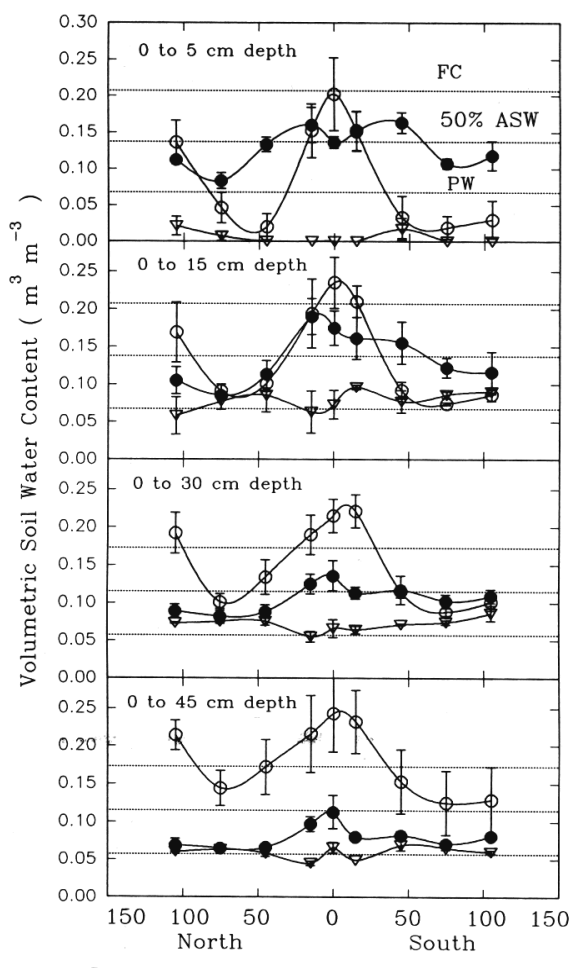

Distance From Emitter, Microjet Or Tree $(\mathrm{cm})$

Fig. 1. Volumetric soil water content vs. lateral distance from emitter, microjet, or tree from soil surface to $5,15,30$, and $45 \mathrm{~cm}$ soil depths for drip $(O)$, microjet $(O)$ and nonirrigation $(\nabla)$ plots. Error bars are SES of means, $n=3$. 
measured by TDR, showed an increase in soil water content $105 \mathrm{~cm}$ north of the drip emitter. Soil water content increased here because this position was $\approx 15 \mathrm{~cm}$ south of the second emitter that irrigated the tree (Fig. 1). For the top $5 \mathrm{~cm}$, volumetric soil water content was $>50 \%$ ASW within a distance of $\approx 20 \mathrm{~cm}$ from drip emitters but extended to $50 \mathrm{~cm}$ from microjets. For the $15-\mathrm{cm}$ soil profile, ASW was $>50 \%$ within a distance of $\approx 30 \mathrm{~cm}$ from drip emitters but extended to $50 \mathrm{~cm}$ from microjets. As expected, microjets covered a larger surface area at shallower depths. For the 30 -cm soil profile, volumetric soil water content was $>50 \%$ ASW within a distance of $\approx 50$ $\mathrm{cm}$ from drip emitters but only within $20 \mathrm{~cm}$ from microjets. For the $45-\mathrm{cm}$ soil profile, all readings were $>50 \%$ ASW for drip emitters (even $>100 \%$ within $50 \mathrm{~cm}$ from drip emitters) and none were $>50 \%$ ASW for microjets. Again, as expected, drip emitters provided a larger volume of water at greater depths. This pattern could have profound implications for the irrigation frequency chosen when watering a tree using different irrigation methods. All readings for the nonirrigated treatment were near or below PWP.

In a contour plot (Cohort's Coplot Software, Berkeley, Calif.) of the drip emitter wetting pattern, as determined by TDR measurements, a distinct cone shape $>50 \%$ ASW $\left(0.137 \mathrm{~m}^{3} \cdot \mathrm{m}^{-3}\right)$ extending from the emitter downward existed (Fig. 2). Jury and $\operatorname{Earl}(1977)$ have generated such contour plots from gravimetric sampling moisture data and obtained a semicircular shape on a Buren sandy loam. They also plotted tensiometer readings 15 and $60 \mathrm{~cm}$ from the emitter with time and noticed a considerable difference in soil water matric potential. Risse and Chesness (1989) plotted soil water matric potential and bromide concentration contours to locate the wetting front on a sandy loam soil and obtained a semicircular shape. In the present study, we observed that, with the drip emitter positioned $60 \mathrm{~cm}$ south of the tree, the first $10 \mathrm{~cm}$ of soil under the tree had volumetric soil water content close to PWP. It was only at a depth of $35 \mathrm{~cm}$ that the moisture level directly beneath the tree reached 50\% ASW. Therefore, the duration of water applications should be minimized to reduce this loss when drip emitters are used.

In a contour plot of microjet wetting pattern from TDR measurements, the 50\% ASW $\left(0.137 \mathrm{~m}^{3} \cdot \mathrm{m}^{-3}\right)$ zone was an elongated semicircle from the soil's surface down to a depth of $35 \mathrm{~cm}$ just beside the tree (Fig. 3). Clothier and Heiler (1983) obtained tracings of the wetting front for various discharge rates on a Chertsey silt loam (Udic Ustochrept), and a large shallow band ( $\approx 30 \mathrm{~cm}$ deep) was observed. When microjets are used, the duration of water applications should be lengthened, depending on the desired depth, to replenish the root zone to adequate water content.

Quantified wetting patterns can be used to develop more efficient irrigation schedules that help reduce chances of deep percolation or water deficit and help maintain suitable moisture for root growth and nutrient uptake.

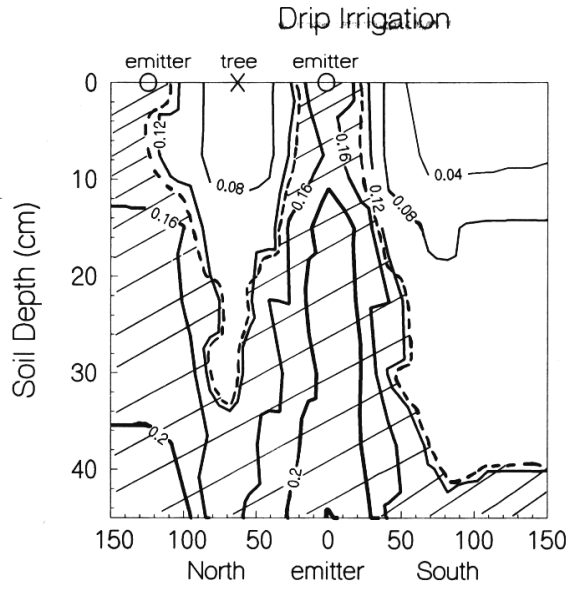

Lateral Distance From Emitter (cm)

Fig. 2. Volumetric soil water content contours for drip irrigation (two emitters per tree) plot receiving 31.5 liters $\cdot$ day $^{-1}$. Dotted line represents $50 \%$ available soil water (ASW) and shaded area represents soil water content $>50 \%$ ASW.

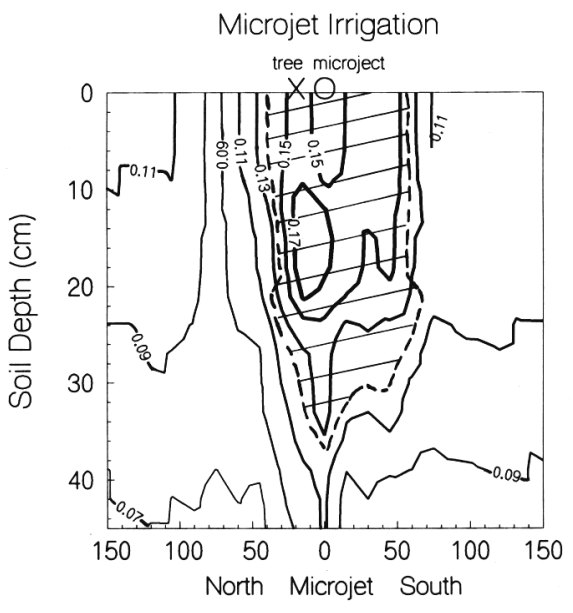

Lateral Distance From Microjet (cm)

Fig. 3. Volumetric soil water content contours for microjet irrigation (one microjet per tree) plot receiving 66.5 liters every 2 days. Dotted line represents $50 \%$ available soil water (ASW) and shaded area represents soil water content $>50 \%$ ASW.

From the drip emitter wetting pattern, we can expect the roots to penetrate deeper into the soil as a result of the deep, cone-shaped wetting pattern. This can be a disadvantage for the tree, since nutrients are concentrated at the shallower depths. Drip irrigation also can lead to anaerobic conditions in the root zone, denitrification, and rapid nutrient leaching because hydraulic conductivity is maximized. However, it may be an advantage during periods of drought, when irrigation is not provided. Under these conditions, the tree can exploit moisture available at greater depths. The microjet wetting pattern shows a definite advantage for nutrient uptake, but more water is required because of its high flow rate (which still resulted in a water deficit in the root zone), which resulted in a lower irrigation efficiency. TDR can be used successfully to determine wetting patterns to improve irrigation scheduling and adapt the schedule to the system in use. In this study, TDR clearly compared the wetting patterns generated by two irrigation methods.

\section{Literature Cited}

Ben-Asher, J., D.O. Lomen, and A.W. Warrick. 1978. Linear and nonlinear models of infiltration from a point source. Soil Sci. Soc. Amer. J. 42:3-6.

Bresler, E., J. Heller, N. Diner, I. Ben-Asher, A. Brandt, and D. Goldberg. 197 1. Infiltration from a trickle source. II. Experimental data and theoretical predictions. Soil Sci. Soc. Amer. Proc. 35:683-689.

Brisco, B., T.J. Pultz, R.J. Brown, G.C. Topp, M.A. Hares, and W.D. Zebchuk. 1992. Soil moisture measurement using portable dielectric probes and time domain reflectometry. Water Resource Res. 28:1339-1346.

Clothier, B. and T. Heiler. 1983. Infiltration during sprinkler irrigation: Theory and field results. Amer. Soc. Agr. Eng. Proc. Natl. Conf. Advances-in Infiltration, 12-13 Dec. 1983, Chicago. p. 275-283.

Clothier, B., D. Scotter, and E. Harper. 1985. Threedimensional infiltration and trickle irrigation. Trans. Amer. Soc. Agr. Eng. 28(2):497-501.

Healy, R.W. and A.W. Warrick. 1988. A generalized solution to infiltration from a surface point source. Soil Sci. Soc. Amer. J. 52:1245-1251.

Jury, W.A. and K.D. Earl. 1977. Water movement in bare and cropped soil under isolated trickle emitters. I. Analysis of bare soil experiments. Soil Sci. Soc. Amer. J. 41:852-856.

Lafolie, F., R. Guennelon, and M.Th. vanGenuchten. 1989. Analysis of water flow under trickle irrigation. II. Experimental evaluation. Soil Sci. Soc. Amer. J. 53:1318-1323.

Levin, I., P.C. van Rooyen, and F.C. van Rooyen. 1979. The effect of discharge rate and intermittent water application by point-source irrigation on the soil moisture distribution pattern. Soil Sci. Soc. Amer. J. 43:8-16.

Nadler, A., S. Dasberg, and I. Lapid. 1991. Time domain reflectometry measurements of water content and electrical conductivity of layered soil columns. Soil Sci. Soc. Amer. J. 55:938943.

Raats, P.A.C. 1971. Steady infiltration from point sources, cavities, andbasins. Soil Sci. Soc. Amer. Proc. 35:689-694.

Risse, L.M. and J.L. Chesness. 1989. A simplified design procedure to determine the wetted radius for a trickle emitter. Trans. Amer. Soc. Agr. Eng. 32(6):1909-1914.

Tan, C.S. and J.M. Fulton. 1981. Estimating evapotranspiration from irrigated crops in Southwestem Ontario. Can. J. Plant Sci. 61:425-435.

Tan, C.S. and R.E.C. Layne. 1991. Soil water content and stomatal conductance in a mature peach orchard as influenced by various irrigation regimes. Can. J. Soil Sci. 71:253-258.

Topp, G.C. and J.L. Davis. 1985. Measurement of soil water content using time domain reflectometry (TDR): A field evaluation. Soil Sci. Soc. Amer. J. 49: 19-24

Topp, G.C., J.L. Davis, W.G. Bailey, and W.D. Zebchuk. 1984. The measurement of soil water content using a portable TDR hand probe. Can. J. Soil Sci. 64:313-321.

Wooding, R.A. 1968. Steady infiltration from a shallow circular pond. Water Resources Res. 4(6): 1259-1273. 